\title{
Asuransi dalam Perspektif Hukum Islam
}

\author{
Muhamad
}

\begin{abstract}
Since takaful has been operated as. a finance and insurance institution in which the investation directed to any legal sectors and the mutual sharing profit determined by two sides, it can be judged that this special system would not break out the Islamic economical principles.
\end{abstract}

\section{Pendahuluan}

Gagasan takaful muncul kepermukaan karena, Islam telah menjiwai dan mewarnai perilaku manusia dalam berfikir, bersikap maupun bertindak dengan batas-batas yang telah ditetapkan, dalam rangka pengabdian kepada Allah SWT. Pada suatu saat Islam bersama umatnya bangkit dan pada saat yang lain tenggelam, sebagaimana begilirnya waktu siang dan malam dalam kehidupan dan sejarah. Setelah melalui perdebatan, selama berabad-abad tentang perilaku bunga uang dalam menentukan perilaku ekonomi manusia, antara diharamkan atau dibolehkan, kini muncul di hadapan kita keputusan di mana terbuka jalan bagi yang mengharamkan bunga, dan bagi yang membolehkan bahkan mengharuskannya. Itulah lembaga-lembaga keuangan yang berbasis syar'iah dan non syariah.

Untuk itu, perlu dipikirkan dan dikaji berbagai kemungkinan dan kelayakan berbagai lembaga keuangan lainnya, sehingga dapat berdiri di Indonesia, sebagai alternatif transaksi keuangan, di negara yang mayoritas beragama Islam. Ini semua dilakukan agar tercipta persaingan yang mengarah kepada terbentuknya efisiensi, dimana produk halal dalam bidang keuangan ini berdaya saing dan berdaya banding tinggi. Dengan kata lain, produk keuangan yang halal 
dalam lembaga keuangan —bank maupun asuransi Islami-tidak harus mahal. Sehingga tidak ada image, bahwa produk yang halal itu harus mahal.

\section{Sistem Perasuransian di Indonesia}

Dilihat dari aspek legal, keberadaan lembaga perasuransian di Indonesia diatur oleh Departemen. Keuangan, khususnya Direktorat Asuransi yang telah mengatur lembaga ini agar tidak merugikan masyarakat. Sebelum diberlakukannya Undang Undang Nomor 2 Tahun 1992 tentang Usaha Perasuransian dan Peraturan Pemerintah Nomor 73 Tahun 1997 tentang Penyelenggaraan Usaha Perasuransian, kegiatan usaha perasuransian di Indonesia hanya diatur dengan Keputusan Menteri Keuangan dan Ordonantie op het Levensverzekering bedrijf (Staatsbland 1941 No. 101).'

Oleh karena itu, setelah diundangkannya UU Nomor 2 Tahun 1992 tentang Perasuransian di Indonesia, maka dalam usaha perusahaan asuransi berjalan mengikuti peraturan-peraturan sebagai berikut:2

1. Undang-undang Nomor 2 Tahun 1992 tentang Usaha Perasuransian

2. Peraturan Pemerintah Nomor 73 Tahun 1992 tentang Penyelenggaraan Usaha Perasuransian

3. Keputusan Menteri Keuangan, masingmasing adalah: a. No: $223 /$ KMK.017/1993 tanggal 26 Februari 1993 tentang perizinan perusahaan asuransi dan perusahaan reasuransi

b. No. $224 / \mathrm{KMK} .017 / 1993$ tanggal 26 Februari 1993 tentang kesehatan keuangan perusahaan asuransi dan perusahaan reasuransi.

c. No. $225 /$ KMK.017/1993 tanggal 26 Februari 1993 tentang penyelenggaraan perusahaan asuransi dan perusahaan reasuransi.

d. No. 226/KMK.017/1993 tanggal 26 Februari 1993 tentang perizinan dan penyelenggaraan kegiatan usaha perusahaan penunjang usaha asuransi.

Berdasarkan peraturan di atas, maka ketentuan-ketentuan yang selama ini digunakan sebagai dasar peraturan pembinaan dan pengawasan usaha perasuransian dinyatakan tidak berlaku lagi. Sebelum diundangkannya Undang-Undang Nomor 2 Tahun 1992 tentang Usaha Perasuransian kegiatan usaha perasuransian hanya diatur dengan Keputusan Menteri Keuangan.

Aktivitas akuntansi secara konvensional secara riil tidak dapat lepas dari pengertian asuransi. Menurut Kitab Undang-undang Hukum Dagang Pasal 246 dinyatakan "asuransi atau pertanggungan adalah suatu perjanjian, dengan mana seseorang penanggung mengikatkan diri kepada seorang tertanggung, dengan menerima suatu premi untuk memberikan penggantian kepadanya

'Dahlan Siamat. 1997. Manajemen Lembaga Keuangan Edisi Kedua. Jakarta: Lembaga Penerbit Fakultas Ekonomi Universitas Indonesia. HIm. 407.

'ibid. 
karena suatu kerugian, kerusakan, atau kehilangan keuntungan yang diharapkan, yang mungkin terjadi karena suatu peristiwa tak tertentu." ${ }^{\text {"3 }}$

Menurut Undang-undang Nomor 2 Tahun 1992 tentang Usaha Perasuransian, dinyatakan: "asuransi atau pertanggungan adalah perjanjian antara dua pihak atau lebih, dengan mana pihak penanggung mengikatkan diri kepada tertanggung, dengan menerima premi asuransi untuk memberikan penggantian kepada tertanggung karena kerugian, kerusahaan atau kehilangan keuntungan yang diharapkan, atau tanggung jawab hukum kepada pihak ketiga yang mungkin akan diderita tertanggung, yang timbul dari suatu peristiwa yang tidak pasti, atau untuk memberikan suatu pembayaran yang didasarkan atas meninggal atau hidupnya seseorang yang dipertanggungkan." ${ }^{4}$

\section{Asuransi dalam Perspektif Islam}

Asuransi dalam perspektif Islam disebut dengan istilah takaful. Menurut etimologibahasa Arab istilah takaful berasal dari akar kata kafala. Dalam ilmu tashrif atau sharaf, takaful ini termasuk dalam barisan bina muła'aadi, yaitu tafaa'ala yang berarti saling menanggung. Sementara ada yang mengartikan dengan makna saling menjamin. Secara terminologi, Evamy (1976) yang dikutip oleh Rahman mendefinisikan, asuransi adalah: suatu kontrak dimana seseorang disebut penjamin asuransi, yang menjalankan. Sebagai balas jasa atas imbalan yang telah disetujui yang disebut premi, untuk membayar orang lain yang diasuransikan, yang disebut tertanggung, sejumlah uang atau yang senilai, atas suatu kejadian tertentu. Peristiwa tertentu itu harus unsur yang tidak menentu; peristiwa tersebut mungkin berupa (a) masalah asuransi jiwa, dalam kenyataan bahwa peristiwa ini dapat terjadi sebagai kejadian sehari-hari, peristiwa terjadi tidak tentu waktunya, atau (b) suatu kenyataan bahwa peristiwa yang dialami disebabkan oleh suatu kecelakaan, yang mungkin peristiwa itu tidäk pernah dialami sama sekali. Kejadian terakhir dinamakan kecelakaan. ${ }^{5}$

Lebih khusus dalam bidang muamalah Juhaya S. Praja yang dikutip oleh Harahap (1997) mengatakan, takaful adalah: Saling memikul resiko di antara sesama orang sehingga antara satu dengan lainnya menjadi penanggung atas resiko yang lainnya. Saling. pikul resiko itu dilakukan atas dasar saling tolong dalam kebaikan dengan cara masingmasing mengeluarkan dana ibadah (tabarru) yang ditunjukkan untuk menanggung resiko tersebut. ${ }^{6}$

Sudah barang tentu, dalam asuransi takaful tidak hanya melibatkan dua pihak yang bertakaful, yakni orang yang saling mengikatkan dirinya untuk saling menjamin resiko yang

\section{${ }^{3}$ Ibid. Him. 367.}

${ }^{4}$ Ibid. Him. 367.

${ }^{5}$ Afzalur Rahman. 1996. Doktrin Ekonomi Islam Jilid 2. Edisi Lisensi. Yogyakarta: Dana Bhakti Wakaf. HIm. 27-28

'Sofyan Syafri Harahap. 1997. Akuntansi Islam. Jakarta: Bumi Aksara. HIm. 99. 
diderita masing-masing, melainkan diperlukan pihak ketiga. Pihak ketiga dimaksud ini adalah lembaga atau badan hukum atau perusahaan yang menjamin kegiatan kerja sama atau takaful ini terjamin berjalan dengan baik dan tidak termasuk.kegiatan yang dilarang oleh syari'at seperti: al-gharar, al-maisir, dan al-riba. ${ }^{7}$ Berkaitan dengan ini menurut Praja, ada unsur-unsur penting yang mesti ada demi terlaksananya takaful, yaitu (a) dua atau beberapa pihak yang bertakaful; dan (b) pengelola takaful. $^{8}$

Mengingat asuransi takaful dioperasional berdasarkan syari'ah Islam, maka dalam lembaga ini dibentuk Dewan Syari'ah. Dewan Syari'ah adalah dewan yang mengeluarkan keputusan produk-produk yang dikeluarkan oleh lembaga asuranși apakah sesuai dengan syari'ah Islam atau tidak, terutama dilihat dari aspek al-gharar, al-maisir, dan al-riba. Program perlindungan menurut syari'ah dikenal dengan Asuransi Takaful yang bertumpu pada konsep wa ta'awanu alal birri wa taqwa ${ }^{9}$ (tolong menolong dalam kebaikan dan taqwa) dan atta'min (rasa aman) yang menjadikan semua peserta asuransi sebagai keluarga besar yang saling menjamin dan menanggung resiko satu sama lainnya.

\section{Pandangan Ulama tentang Asuransi}

Pandangan para ulama, khususnya fuqaha', di bidang syari'ah merupakan pencerminan dari pandangan Islam mengenai soal-soal kehidupan manusia, baik di bidang ibadah maupun muamalah. Berkaitan dengan masalah asuransi yang termasuk dalam hal muamalah, yang harus dihadapi oleh dunia Islam sebagai akibat dari hubungannya dengan dunia Barat, telah mendapatkan tanggapan dari para ulama, terutama pada abad ke-20.

Para ulama yang membahas masalah asuransi beranggapan bahwa masalah merupakan masalah yang belum pernah dikenal sebelumnya, sehingga hukumnya yang khas tidak ditemukan dalam fiqh Islam. Cukup banyak para ulama yang menaruh perhatian pada masalah asuransi ini, baik yang melontarkan pendapatnya dalam bentuk fatwa maupun dalam bentuk buku, dan sebagainya.

Sebagai contoh misalnya, ulama yang bermazab Hanafiyah, yaitu Ibnu 'Abidin (17841836), yang dikutip Yafie menegaskan, bahwa:

... telah menjadi kebiasaan bilamana para pedagang menyewa kapal dari seorang harby, mereka membayar upah pengangkutannya. la juga membayar sejumlah uang untuk seorang harby yang berada di negeri asal penyewa kapal, yang disebut sebagai sukarah (premi asuransi), dengan ketentuan bahwa barang-barang pemakai kapal yang berada di kapal yang disewanya itu, bilamana musnah karena kebakaran, atau kapal tenggelam, atau dibajak dan sebagainya, maka penerima uang premi asuransi itu menjadi penanggung,

${ }^{7} /$ bid.

8/bid.

${ }^{9} \mathrm{QS}$. Al-Maidah: 3. 
sebagai imbalan dari uang yang diambil dari pedagang itu. Penanggung itu mempunyai wakil yang mendapat perlindungan yang di negeri kita berdiam di kota-kota pelabuhan negara Islam atas seizin penguasa. Si wakil tersebut menerima uang premi asuransi dari para pedagang itu, dan bilamana barangbarang mereka tertimpa peristiwa yang disebutkan di atas, dia (si wakil) lah yang membayar kepada para pedagang itu sebagai uang pengganti sebesar sejumlah yang pernah diterimanya. ${ }^{10}$

Pendapat lain, dikemukakan oleh Muhammad Abduh (1849 - 1905), di dalam majalah al-Muhamat Tahun $V$ No. 460 , Abduh memfatwakan, bahwa pekerjaan perusahaan asuransi jiwa adalah pekerjaan mubah (hukumnya), karena persetujuan orang/ seorang dengan para pemilik perusahaan asuransi tergolong syirkah al-mudharabah, dan boleh dikerjakan (ja'iz). Dengan demikian Abduh adalah ulama yang pertama memperbolehkan asuransi jiwa dengan akad mudharabah.

Sebagai bahan penguat pendapat para ulama tersebut, ternyata pernah di adakan seminar Fiqh Islam yang diselenggarakan oleh al-Majlis al-A'la; I Ri'ayah al-Funun wa alAdab wa al'Ulum. al-litima'iyah di Damsyik. Dalam membahas beberapa persoalan di sekitar asuransi, seminar ini tidak merumuskan suatu pendapat bersama, kecuali hanya menginventrasisasikan serta mendiskusikan pendapat-pendapat yang berkembang dalam pertemuan tersebut.
Beberapa poin pendapatnya adalah sebagai berikut:

1. Masalah asuransi adalah hal baru, tidak ada nash-nya dalam syari'ah

2. Menyanggah pendapat ulama yang mengharamkan asuransi karena digolongkan ke dalam jenis pertaruhan atau untung-untungan. Menurutnya, unsur saling menolong yang ada dalam asuransi itu menjauhkan dari jenis pertaruhan.

3. Menyanggah adanya kesamaran dalam 'aqd al-ta'min;

4. Perusahaan asuransi memutar dana cadangan dengan jalan riba, yang darinya kelak tertanggung dalam asuransi jiwa, apabila tetap hidup sampai berakhirnya jangka waktu pertanggungnya, mendapat sejumlah uang dengan bunganya sebagai pengganti uang .premi yang pernah dibayarnya. Ini hukumnya haram menurut hukum agama. Cara ini merupakan praktik yang dilakukan perusahaani-perusahaan asuransi, hal mana harus dipisahkan dengan persoalan asuransi sendiri selaku satu sistem atau lembaga hukum.

5. Asuransi mempunyai sua bentuk: asuransi bersama (perkumpulan) dan asưransi perusahaan. Bentuk pertamà hendaknya diprioritaskan, karena bersifat saling menolong belaka. Tetapi karena mendapat banyak kesulitan dan ketidakmampuan dalam arena perekonomian, perhatian akhirnya menjadi lebih tertuju kepada asuransi perusahaan.

6. Asuransi perusahaan halal menurut hukum syara', karena dapat dikiaskan

${ }^{10}$ Ali Yafie. "Asuransi dalam Perspektif Islam." JumalKebudayaan dan Peradaban Ulumul Qur'an. No. 2NVII/1996. HIm. 4-14. 
pada 'aqd al-muwalat menurut mazhab Maliki, nizham al-awaqil dan sistem pensiun bagi pegawai negeri."

Dari beberapa pendapat ulama tersebut telah memberikan gambaran jelas, walaupun masih harus dijelajahi lebih jauh tentang halhal penting yang terkait dalam pemasalahan yang dibahas. Dengan pengungkapan segisegi penting dari masalah asuransi, seperti peristilahan, definisi, sejarah, perkembangan, bentuk-bentuk, sifat, dan tujuan dari asuransi, maka tampak upaya memperoleh gambaran yang diperlukan sebagai titik tolak dari pembahasan utama masalah ini.

\section{Perkembangan Asuransi Takaful}

Sebelum muncuinya asuransi takaful di Indonesia, ternyata asuransitakaful sudah lahir di berbagai negara baik di negara muslim (Arab, Malaysia) maupun non-muslim (Swiss, Bahamas, Inggris). Di antara asuransi takaful tersebut adalah tersebar di negara-negara sebagai berikut: 12

1. Islamic Insurance Co. Ltd. Sudan (1979)

2. Islamic Arab Insurance C. Ltd. Saudi Arabia (1979)

3. Dar Al-Maal Al Islami Geneva (1983)

4. Takaful Islami Luxemburg (1983)

5. Takaful Islam Bahamas (1983)

6. Al-Takaful Al-Islami Bahrain (1983)

7. Syarikat Takaful Malaysia SDN. Berhad
(1984)

8. Syarikat Takaful Brunei Darussalam

9. Asuransi takaful Indonesia (1993)

Menurut survey yang dilakukan Harian Republika dilaporkan bahwa asuransi Takaful terbaik adalah Syarikat Takaful Malaysia. ${ }^{13}$ Pengalaman di Malaysia ternyata cash inflow yang diterima oleh pemegang polis ternyata pada tahun pertama telah melampaui atau lebih besar dari cash inflow yang diterima dari perusahaan asuransi konvensional. Hasil ini dapat dicapai karena sistem manajemen yang profesional telah diterapkan, sedang di asuransi konvensional baru dicapai pada tahun ketiga.

\section{Prinsip Asuransi Takaful}

Sesuai dengan tujuan dibentuknya asuransi takaful, maka kerangka operasional asuransi takaful didasarkan pada prinsipprinsip. Prinsip-prinsip inilah yang merupakan penyangga operasionalnya asuransi takaful. Perwataatmadja (1994) mengungkapkan, bahwa "prinsip asuransi takaful adalah penghayatan terhadap semangat saling bertanggungjawab, kerjasama dan perlindungan dalam kegiatan masyarakat, demi tercapainya kesejahteraan umat dan masyarakat umumnya. ${ }^{14}$ Sementara Yusof mengungkapkan, bahwa prinsip operasional asuransi takaful adalah:

\section{"1'bid.}

${ }^{12}$ Harahap. Op.Cit. HIm. 99.

${ }^{13}$ Harian Republika edisi 3/9/'93. HIm 16.

${ }^{14}$ Muhamad. 2000. Lembaga-lembaga Keuangan Umat Kontemporer. Yogyakarta : Ull Press. HIm. 75. 
As the essence of insurance could be seen in the system of mutual help in relation to the custom of blood money under the Arab tribal custom, Muslim.jurist generally accepted that the concept of insurance does not contradict with the Shariah. In fact, the prinsiple of compensation and group responsibility was accepted by Islam and the Holy Prophet. Muslim jurists acknowledged that the basis of shared responsibility in the system of 'aqila', as practiced between Muslims of Mecca (muhajirin) and Medina (ansar) laid the foundation of mutual insurance. ${ }^{15}$

Jadi sejak lama sistem aqila memang telah terdapat dalam literatur Islam dan dipraktekkan oleh masyarakat Islam. Dengan kata lain, istilah tanggung renteng atau social insurance sudah ada sejak zaman awal Islam. Berdasarkan pemikiran tentang prinsip asuransi takaful, maka secara mendasar prinsip tersebut adalah: ${ }^{16}$

a. Prinsip Saling. Bertanggungjawab. Banyak hadist Nabi SAW yang mengajarkan bahwa hubungan umat beriman dalam rasa kasih sayang satu sama lain, ibarat satu badan, yang apabila salah satu anggota badannya terganggu atau kesakitan, maka seluruh badan akan ikut merasakan, tidak dapat tidur dan terasa panas. Islam mengajarkan agar manusia menyucikan jiwa mengurangkan sebanyak mungkin perasaan mementingkan diri sendiri. Rizki Allah yang berupa harta benda hendaklah disyukuri, jangan hanya dinikmati sendiri, tetapi digunakan juga untuk memenuhi kepentingan masyarakat, meringankan beban penderitaan dan meningkatkan taraf hidup mereka.

b. Prinsip Saling Bekerjasama atau Saling Bantu Membantu. Allah memerintahkan agar dalam kehidupan bermasyarakat ditegakkan nilai tolong menolong dalam kebajikan dan taqwa.

c. Prinsip Saling melindungi Penderitaan Satu Sama Lain. Islam mengajarkan bahwa keselamatan dan keamanan merupakan tuntutan alami dalam hidup manusia, seperti halnya mencari rizki adalah merupakan tuntutan alami dalam hidup manusia.

Tiga prinsip asuransi takaful tersebut tidak mungkin terjabarkan dalam kehidupan nyata jika tidak dilandasi iman dan taqwa kepada Allah yang mantap. Niat yang ikhlas untuk membantu sesama yang mengalami. penderitaan karena musibah, atau meringankan atau berbagi resiko dengan orang yang mengalami musibah, merupakan landasan awal dalam asuransi takaful. Premi yang dibayarkan kepada perusahaan asuransi takaful harus didasarkan kepada tabarru' (sedekah), guna mendapat ridha Allah. ${ }^{17}$

\section{${ }^{15} \mathrm{lbid}$ \\ ${ }^{16} \mathrm{Jbid}$}

${ }^{17}$ Ahmad Azhar Basyir. "Takaful sebagai Alternatif Asuransi Islam." Jurnal Kebudayaan dan Peradaban Ulumul Qur'an. No. 2NII/1996. HIm. 15-21 


\section{Jenis-jenis Asuransi Takaful}

Di dalam asuransi takaful yang sebenarnya terjadi adalah saling bertanggung jawab, bantu membantu dan melindungi para peserta sendiri. Perusahaan asuransi takaful diberi kepercayaan (amanah) oleh para peserta untuk mengelola premi para peserta, mengembangkan dengan jalan halal, memberikan santunan kepada yang mengalami musibah sesuai isi akta perjanjian. Berkaitan dengan itu, maka asuransi takaful dapat menawarkan dua jenis pertanggungan, yaitu:

\section{Takaful Keluarga (Asuransi Jiwa) \\ 2. Takaful Umum (Asuransi Umum)}

Takaful Keluarga adalah bentuk takaful yang memberikan perlindungan dalam menghadapi musibah kematian dan kecelakaan atas diri peserta takaful. Dalam musibah kematian yang akan menerima santunan sesuai perjanjian adalah keluarga / ahli warisnya, atau orang yang ditunjuk, dalam hal tidak ada ahli waris. Dalam musibah kecelakaan yang tidak mengakibatkan kematian, santunan akan diterima oleh peserta yang mengalami musibah. Jenis takaful keluarga meliputi:

a. Takaful dengan unsur tabungan, meliputi:

Takaful Berencana / Dana Investasi;

Takaful Dana Haji; Takaful Pendidikan/

Dana Siswa

ob. Takaful tanpa unsur tabungan, meliputi:

Takaful Berjangka; Takaful Majelis Ta'lim;
Takaful Khairat Keluarga; Takaful

Pembiayaan; Takaful Kecelakaan Diri;

Takaful Wisata dan Perjalanan; Takaful

Kecelakaan Siswa; Takaful Perjalanan Haji dan Umroh

Takaful Umum adalah bentuk yang memberi perlindungan dalam menghadapi bencana atau kecelakaan atas harta milik peserta takaful, seperti rumah, kendaraan, bermotor, bangunan pabrik dan sebagainya. Jenis Takaful Umum meliputi: Takaful Kebakaran; Takaful Kendaraan Bermotor; Takaful Resiko Pembangunan; Takaful Pengangkutan Barang; Takaful Resiko Mesin.

\section{Mekanisme Pengelolaan Dana Takaful}

Dana asuransi Takaful Keluarga diperoleh dari pemodal dan peserta asuransi didasarkan atas niat dan semangat persaudaraan untuk saling bantu membantu pada waktu diperlukan. Hal penting yang harus diikuti dalam mekanisme pengelolaan dana takaful adalah bahwa daiam pengelolaan dana tidak melibatkan unsur-unsur yang bertentangan dengan syari'ah Islam. Pada Asuransi Takaful Keluarga pengolahan dananya terdiri dari dua cara, yaitu premi dengan unsur tabungan dan premi tanpa unsur tabungan.

\section{Premi dengan Unsur Tabungan}

Alur mekanisme pengelolaan dana takaful yang disertai dengan unsur tabungan adalah sebagai berikut: ${ }^{18}$

\footnotetext{
${ }^{19} \mathrm{lbid}$.
} 


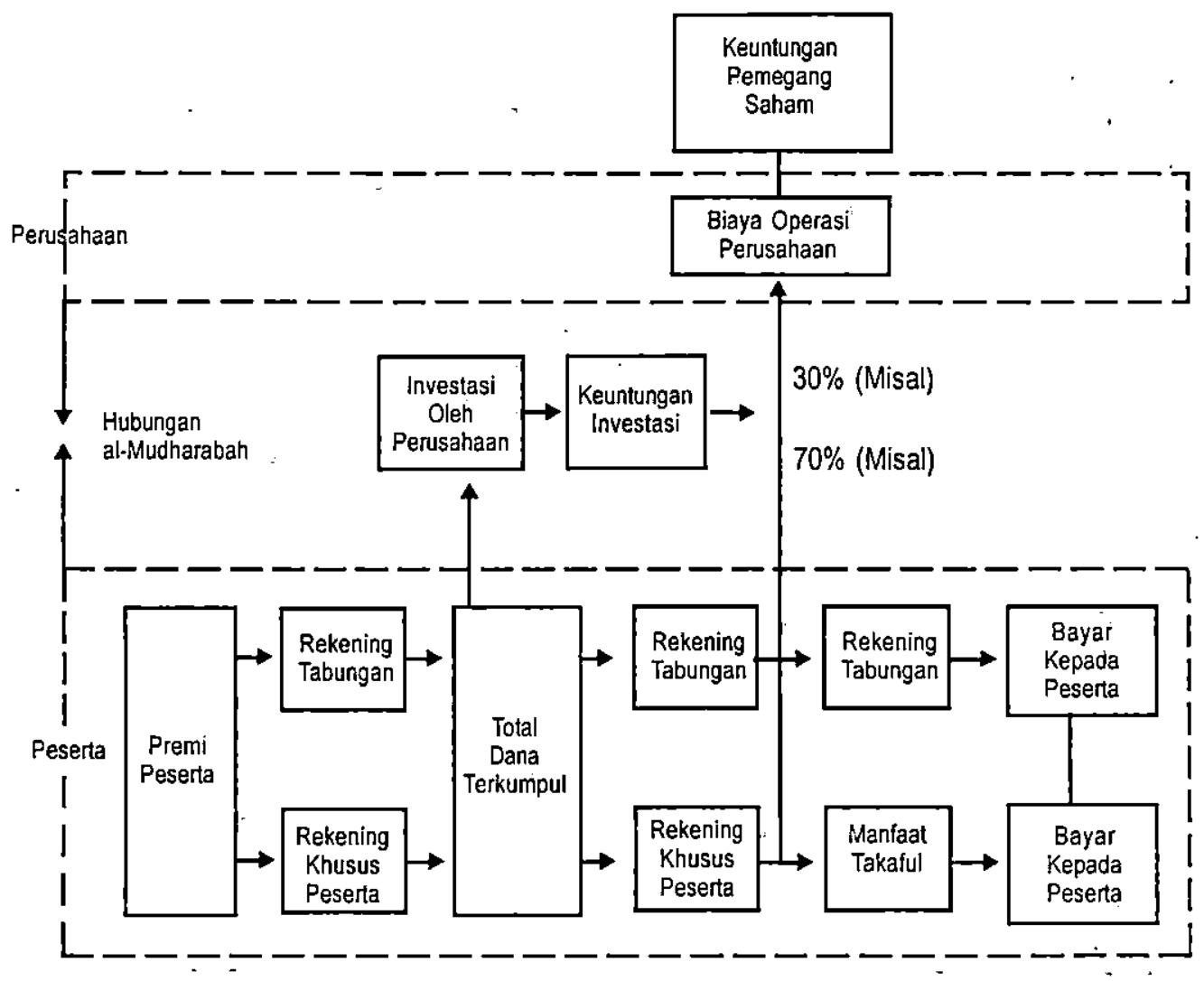

Pendekatan ini dikelola, bahwa setiap iuran premi dari seorang peserta yang masuk ke perusahaan takaful langsung dipecah menjadi dua bagian, yaitu:

1. Rekening peserta (participant's account), yaitu rekening tabungan peserta

2. Rekening peserta khusus (participant's special account atau charity account), yaitu" uang yang diniatkan sebagai dana kebajikan (tabarru) dan digunakan untuk membayar klaim (manfaat takaful) kepada ahli waris, bila ada peserta yang ditakdirkan meninggal dunia. Besarnya rekening peserta khusus tergantung pada tingkat usia dan jangka waktu pertanggungan. Rekening ini besarnya antara 5 sampai 30 persen dari iuran premi. Semakin tua usia peserta, maka semakin besar tabarrunya.

Penentuan pembagian rekening ini semata untuk berjalannya usaha perusahaan secara transparan dan menghilangkan keraguan mengenai dari mana datangnya dana untuk membayar klaim. Sejak awal peserta sudah diminta untuk menghibahkan $5-30$ persen uang preminya yang dimasukkan ke dalam rekening peserta khusus, guna membayar klaim apabila terjadi musibah pada sebagian peserta. 
Seluruh premi takaful akan disatukan ke dalam Kumpulan Dana. Peserta yang selanjutnya diinvestasikan secara syari'ah. Keuntungan yang diperoleh akan dibagikan sesuai dengan perjanjian al-mudharabah (bagi hasil) yang telah disepakati bersama, yaitu misalnya $70 \%$ dari keuntungan untuk peserta dan $30 \%$ untuk perusahaan. Bagian keuntungan milik peserta $(70 \%)$ akan ditambahkan ke Rekening Peserta (Tabungan) dan Rekening Khusus secara proporsional. Bagian keuntungan milik perusahaan $(30 \%)$ akan digunakan untuk membiayai operasional perusahaan. Dengan demikian, rekening tabungan peserta akan dibayarkan bila: a. Pertanggungan berakhir

b. Peserta mengundurkan dịi dalam masa perjanjian

c. Peserta meninggal dunia dalam masa perjanjian

Rekening khusus akan dibayarkan bila:

a. Peserta meninggal dunia dalam masa perjanjian

b. Pertanggungan berakhir dalam hal terdapat net surplus.

\section{Premi Tanpa Unsur Tabungan}

Alur mekanisme pengelolaan dana takaful tanpa disertai dengan unsur tabungan adalah sebagai berikut : ${ }^{19}$

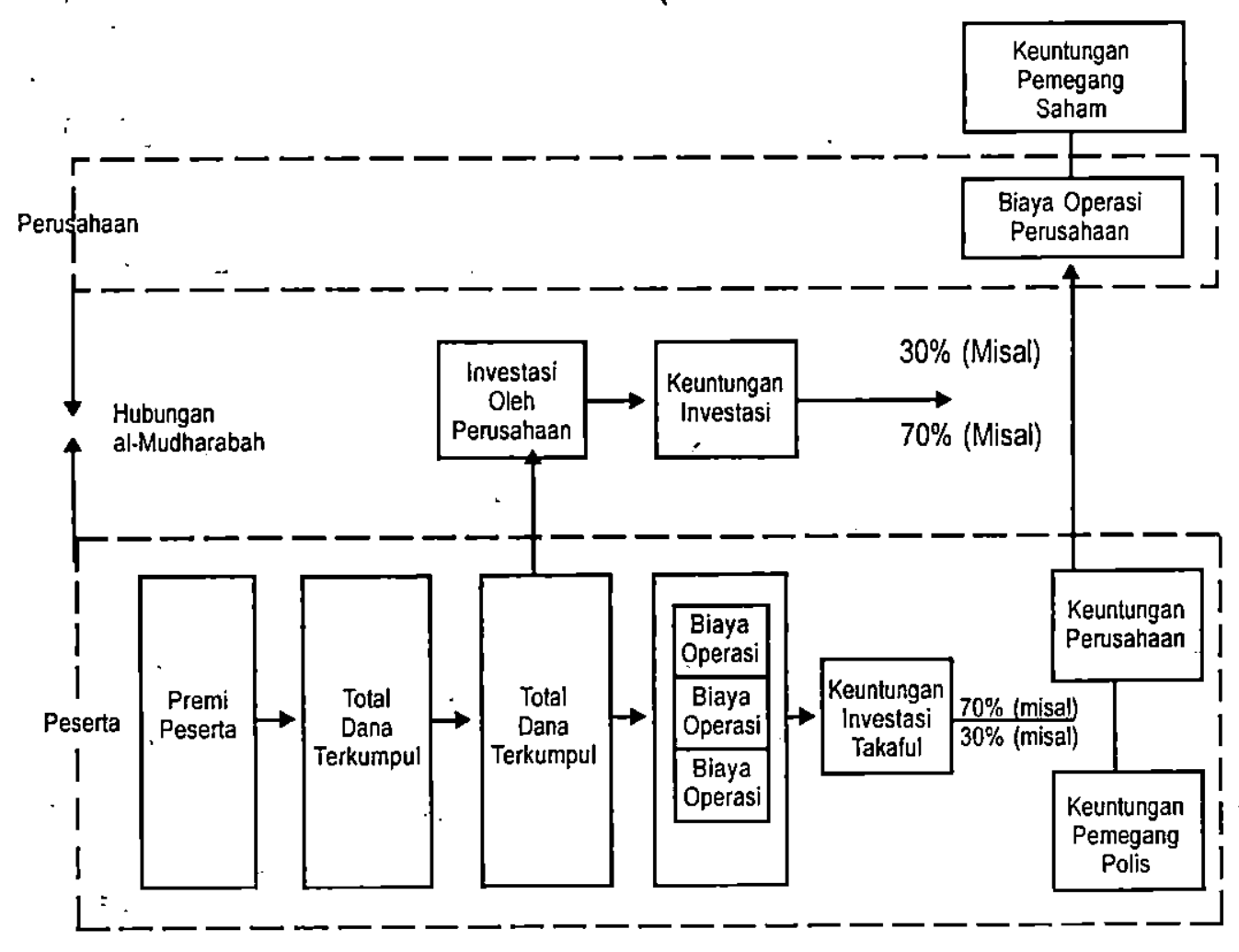

${ }^{19} /$ bid 
Mekanisme premi tanpa unsur tabungan dilakukan dengan setiap premi Takaful yang diterima akan dimasukkan ke dalam Rekening Khusus, yaitu kumpulan dana yang diniatkan untuk tujuan kebajikan atau tabarru guna pembayaran klaim kepada peserta apabila terjadi musibah atas harta benda peserta mengalami kerugian. Premi Takaful akan dikelompokkan ke kumpulan dana peserta untuk kemudian diinvestasikan secara syari'ah. Keuntungan investasi yang diperoleh - akan dimasukkan ke kumpulan dana peserta untuk kemudian dikurangi biaya asuransi (klaim). Apabila terdapat kelebihan sisa dana, maka akan dibagikan kepada peserta dan perusahaan menurut prinsip al-mudharabah (bagi hasil), 30\% keuntungan untuk peserta dan $70 \%$ untuk perusahaan.

\section{Perbedaan antara Takaful dengan Asuransi Konvensional}

Terjadi perbedaan mendasar antara asuransi takaful dengan asuransi konvensional.
Asuransi konvensional umumnya memakai dasar ikatan pertukaran, ialah pertukaran antara pembayaran premi asuransi dengan uang pertanggungjawaban. Dalam syariah Islam pertukaran tersebut harus jelas berapa yang harus dibayarkan dan berapa yang harus diterima sehingga mengandung unsur ketidak pastian dalam aqad.Permasalahan lainnya apabila putus ditengah jalan, tidak bisa dipastikan berapa haknya yang akan diperoleh dan kemungkinan besar hangus sehingga mengandung unsur dholim. Dana yang dihimpun oleh lembaga asuransi kemudian mereka investasikan untuk usaha, maka dasar untuk berpijak adalah sistem bunga sehingga mengandung unsur riba. Dengan berdasar pertimbangan tersebut, maka Majelis Ulama Malaysia, yaitu Kuasa Fatwa, pada tanggal 15 Juni 1972 menetapkan bahwa praktik asuransi jiwa konvensional hukumnya menurut islam adalah haram.

Secara prinsip perbedaan antara ásuransi konvesional dengan asuransi takaful dapat dilihat dari berapa segi terangkum dalam tabel berikut: 
Tabel 1.

Perbedaan antara Asuransi Biașa dengan Takaful

\begin{tabular}{|c|c|c|}
\hline TOPIK & ASURANSI BIASA & TAKAFUL (ASURANSI SYARIAH) \\
\hline Prinsip dasar & $\begin{array}{ll} & \text { Akad pertukaran (jual beli) } \\
\text { - } & \text { Kerja sama } \\
\text { - Hukum } \\
\text { - Ekonomi } \\
\text { - Aktuaria }\end{array}$ & $\begin{array}{ll} & \text { Akad saling melindungi (takaful) } \\
\text { - } & \text { Tolong menolong } \\
\text { - Saling melindungi } \\
\text { - Saling bertanggung jawab } \\
\text { - Saling bekerja sama }\end{array}$ \\
\hline $\begin{array}{l}\text { Sistem dan Operasional } \\
\text { - Pengelolaan dana }\end{array}$ & $\begin{array}{l}\text { - Perusahaan sebagai pemilik dana } \\
\text { - Dana diinvestasikan sesuai } \\
\text { - Bengan kebijakan manajemen } \\
\text { Bunga }\end{array}$ & $\begin{array}{l}\text { - Perusahaan sebagai pemegang } \\
\text { amanah } \\
\text { - Kebijaksanaan investasi sesuai } \\
\text { dengan syari'ah } \\
\text { - Bagi hasil (mudharabah) }\end{array}$ \\
\hline - Biaya & $\begin{array}{l}\text { - Biaya ditanggung pemegang } \\
\text { polis }\end{array}$ & $\begin{array}{l}\text { - Pemegang polis hanya menanggung } \\
\text { biaya sebagian kecil saja berdasarkan } \\
\text { kesepakatan kedua belah pihak }\end{array}$ \\
\hline - Premi & $\begin{array}{l}\text { - Mortalita } \\
\text { - Biaya (alpa, beta, gamma) } \\
\text { - Bunga }\end{array}$ & - Mortalita/harapan hidup (net premium) \\
\hline
\end{tabular}

Sumber: Syarikat Takafu! Indonesia.

\section{Simpulan}

Konsep Takaful bersendikan pada asas saling membantu atau gotong royong dan kerjasama untuk saling membantu serta saling melindungi dengan penuh rasa tanggungjawab apabila ada peserta yang tertimpa musibah. Asuransi Takaful adalah asuransi yang didalamnya terdapat kekhususan operasional. Kekhususan sistem operasi Takaful terletak pada dua bidang, yaitu: (1) Adanya arahan terhadap investasi dari dana yang terkumpul ke sektor-sektor investasi yang tidak bertentangan dengan syari'ah Islam, dan (2) adanya porsi bagi hasil yang dapat diterima oleh peserta asuransi / tertanggung. Dengan mekanisme bagi hasil ini, sehingga masalah keraguan apakah aktivitas takaful masuk dalam kategori riba atau tidak, maka dapat dijelaskan. Hal demikian ini diperbolehkan dalam hukum Islam.

Masalah arahan investasi agar sejalan dengan prinsip-prinsip dalam syari'ah Islam dan aturan tentang Bagi Hasil bagi para peserta asuransi/ tertanggung, belum diatur dalam Undang-Undang No. 2 Tahun 1992. Namun, secara umum dapat dikatakan bahwa bentuk asuransi takaful tampaknya tidak bertentangan dengan ketentuan per UndangUndangan dan Peraturan yang berlaku. Diperkenalkannya asuransi takaful sebagai suatu produk asuransi baru di Indonesia diharapkan dapat memenuhi kebutuhan masyarakat yang pada saat ini mulai tumbuh 
kesadaran berasuransi. Sehingga di samping ikut membangun dan memperkuat sumber daya keuangan di dalam negeri juga akan memberikan dampak kontraksi moneter, dan dengan optimalisasi dalam investasi yang dilakukan sesuai dengan prinsip syari'ah Islam akan dapat membantu pertumbuhan ekonomi.

Di samping, pertimbangan kepentingan makro di atas, diperkenalkannya asuransi takaful sebagai produk tambahan dari program-program asuransi yang telah ada akan menghasilkan efek sinergi yaitu terbukanya segmen-segmen pasar bagi permintaan terhadap asuransi takaful, maka pasar bagi asuransi secara keseluruhan akan dengan sendirinya berkembang pula. Hal ini disebabkan karena di samping perusahaan asuransi akan merespons keadaan melalui inovasi produk dan peningkatan pelayanan, juga akan terjadinya variasi dalam lingkungan pasar dengan efek meningkatnya permintaan. Perkembangan yang demikian ini dalam lingkup mikro sudah barang tentu secara relatif akan meningkatkan produksi premi masingmasing perusahaan.

Prospek perkembangan asuransi takaful di Indonesia akan dapat dianalisis jika dipelajari tentang perkembangan asuransi yang pernah ada di Indonesia, dengan memperhatikan struktur pasar dan perkembangan premi asuransi. Barangkali data terlampir dapat dijadikan trend perkembangan, walaupun data tersebut muncul pada sepuluh tahun yang lalu, bahwa struktur pasar dan performa usaha dan jumlah perusahaan asuransi jiwa dari tahun 1987 sampai dengan tahun 1992 mengalami kenaikan $12 \%$. Jika kenaikan ini dihubungkan dengan perkembangan premi asuransi jiwa dengan peningkatan rata-rata $20 \%$ per tahun dalam periode tahun yang sama, maka sekilas tampak bahwa pertambahan jumlah perusahaan secara elastis telah menghasilkan pertambahan produksi premi asuransi jiwa dalam jumlah lebih besar. Indikator yang sama dapat dilihat juga pada perkembangan sektor asuransi kerugian dengan kenaikan jumlah perusahaan rata-rata $6 \%$ per tahun mulai tahun 1987 sampai dengan tahun 1992 dan peningkatan jumlah produksi premi sebesar rata-rata $16 \%$ per tahun.

Berkenaan dengan keberadaan asuransi takaful di Indonesia, ada beberapa faktor yang dapat dijadikan tolok ukur untuk melihat perkembangannya, selain indikator data-data di atas. Faktor-faktor yang mempengaruhi permintaan terhadap asuransi adalah faktor endogenous dan exogenous.

Faktor endogenous diantaranya adalah termasuk kemakmuran, tingkat pendapatan, gaya hidup, adat dan tradisi bahkan tingkat keberagamaan. Masing-masing faktor ini akan menentukan tingkat keputusan seseorang untuk membeli suatu jasa asuransi tertentu, walaupun keberadaannya masih sangat relatif dan tergantung pada lokalitas dan lingkungan di sekitarnya. Namun demikian, tingkat pendidikan, pengetahuan dan kesadaran akan kebutuhan jasmani dan rohani masyarakat kita yang pada umumnya sudah berkembang, diharapkan dapat memicu meningkatnya permintaan terhadap jasa-jasa asuransi yang lebih sesuai dengan kondisi sosio ekonomi dan religi masyarakat.

Faktor exogenous adalah faktor dari luar diri manusia, tetapi dapat mendorong seseorang menentukan keputusan untuk membeli suatu jasa. Dengan kata lain, faktor exogenous merupakan faktor dari luar tetapi dapat mendorong terjadinya permintaan, 
barangkali cukup relevan untuk diuraikan dalam konteks ini. Faktor-faktor tersebut antara lain, produk asuransi takaful itu sendiri, mulai dari bentuk dan batas penutupan, tingkat suku premi, dan hal-hal yang spesifik dan menarik lainnya. Faktor lain misalnya peraturan pemerintah, perpajakan atau ketentuan lain yang dapat mendorong seseorang membeli asuransi takaful. Contoh para nasabah Bank Muamalat mengutamakan mengasuransikan dirinya dengan membeli asuransi jiwa takaful, dan lain-lain.

Dengan mencermati faktor-faktor di atas, maka produk asuransi takaful akan memiliki prospek pasar yang cukup potensial. Satu hal yang tidak boleh dilewatkan dalam operasional dan kajian asuransi takafu! adalah aspek penyebaran resikonya. Penyebaran resiko melalui metode reasuransi adalah merupakan suatu kebutuhan mutlak agar suatu asuransi dapat beroperasi dengan baik, sebagaimana prinsip ini dikenal dengan sebutan speading of risk. Dalam kenyataannya, reasuransi tidak sekedar suatu mekanisme penyebaran resiko akan tetapi telah berkembang membentuk suatu industri reasuransi dengan para pelaku yang pada umumnya perusahaan-perusahaan yang memiliki kekuatan-kekuatan yang sangat menentukan pergerakan dan perusahan pasar asuransi, terutama pada asuransi kerugian.

\section{Daftar Pustaka}

Basyir, Ahmad Azhar. "Takaful sebagai Alternatif Asuransi Islam." Jurnal Kebudayaan dan Peradaban Ulumul Qur'an. No. 2N II/1996. HIm. 15-21.

Departemen Agama, Al-Qur'an dan Terjemahnya.

Harahap, Sofyan Syafri. 1997. Akuntansi Islam. Jakarta: Bumi Aksara.

Harian Umum Republika edisi 3/9/ '93. HIm 16.

Muhamad. 2000. Lembaga-lembaga Keuangan Umat Kontemporer. Yogyakarta: UII Press.

Rahman, Afzalur. 1996. Doktrin Ekonomi Islam Jilid 2. Edisi Lisensi. Yogyakarta: Dana Bhakti Wakaf.

Siamat, Dahlan. 1997. Manajemen Lembaga Keuangan Edisi Kedua. Jakarta: Lembaga Penerbit Fakultas Ekonomi Universitas Indonesia.

Yafie, Ali. "Asuransi dalam Perspektif Islam". Jurnal Kebudayaan dan Peradaban Ulumul Qur'an. No. 2NII/1996. 